\title{
WELFARE REFORM FOR LOW-WAGE WORKERS IN NEW ZEALAND: WILL WORKING FOR FAMILIES WORK?
}

\author{
Patrick Nolan' \\ School of Government \\ Victoria University of Wellington
}

\begin{abstract}
In May 2004 the New Zealand Government announced a number of welfare reforms (the Working for Families reforms) that will account for an increase in welfare expenditure of approximately $\$ 1.1$ billion per-annum when fully implemented. Two objectives of these reforms are to reduce child poverty and to improve financial incentives for work at low wages. This paper evaluates the effectiveness of these reforms in achieving these objectives. Research is cited that shows that Working for Families should significantly reduce child poverty. This research, however, contains no estimates of the labour market behavioural effects of the reforms. This paper therefore estimates the likely labour market behavioural effects of the reforms and the impact of these effects on poverty reduction effectiveness and targeting efficiency. The improvement in financial incentives for work facing sole parents will be likely to improve the poverty reduction effectiveness of the reforms. The increase in disincentives facing secondary earners will be likely to encourage partnered families to reduce their hours of work and market incomes. These responses will be likely to improve the targeting efficiency of the reforms but at a cost of increasing the excess burden of the welfare system.
\end{abstract}

\section{Introduction}

This paper evaluates the effectiveness of the Working for Families (WFF) reforms in reducing child poverty and improving the financial incentives for work at low wages. This paper first summarises the key features of WFF. Issues in measuring poverty and the reduction in headcount rates of poverty following WFF are then considered. This is followed by an evaluation of issues in estimating financial incentives to supply labour and the changes in these financial incentives following WFF. The impact of these changes in financial incentives on poverty reduction effectiveness and targeting efficiency are then discussed.

\section{The Working for Families Reforms}

On 27 May 2004 the Minister of Social Development, the Hon. Steve Maharey, announced a number of welfare reforms targeting low-wage families with children. These reforms are forecast to account for an increase in government expenditure on the welfare system of approximately $\$ 1.1$ billion per-annum when fully implemented by 1 April 2007. Key features of these reforms are:

- October 2004: remove abatement of Accommodation Supplement during the $\$ 80$ gross per-week earnings' disregard for main benefit abatement; increase the thresholds at which non-beneficiary families' Accommodation Supplement begins to abate; and increase Childcare and OSCAR Subsidy rates.

- April 2005: increase Family Support Rates (\$25 perweek for the eldest child and $\$ 15$ per-week for additional children); remove child component of main benefits; and increase Accommodation
Supplement areas from three to four, with increases in the maximum rates of assistance in some areas.

- October 2005: further increases in Childcare and OSCAR Subsidy rates.

- April 2006: replace the $\$ 15$ per-child Child Tax Credit with an In-Work Payment of $\$ 60$ per-week (with $\$ 15$ per-child top-up for the fourth and additional children) available to families not receiving a main benefit and working 30 hours perweek if a couple or 20 hours per-week if single; remove abatement of Family Assistance on incomes between $\$ 20,356$ and $\$ 27,500$; and increase the Family Tax Credit, from providing a guaranteed minimum family income of $\$ 15,080$ net to providing $\$ 17,000$ net.

- April 2007: increase Family Support rates by $\$ 10$ per-child per-week.

The Family Assistance programmes are also to be indexed to inflation, with the rates and thresholds increasing when Consumer Price Index increases reach a total of five percent.

\section{Estimating Poverty Reduction}

A central objective of WFF is to reduce child poverty. To help evaluate the success of these reforms in achieving this objective this section of the paper canvasses some of the variety of ways of conceptualising and techniques for measuring poverty.

Poverty can be seen as a lack of adequate command over resources. Resources may include monetary income, non-monetary income (such as the imputed income from domestic labour and assets such as housing), 
consumption, and endowments (including financial and human capital endowments). Unfortunately it is not possible to quantify many forms of income, consumption, and endowments. Further, even where resources can be quantified there may be difficulties in collecting and evaluating data. Consequently poverty measures often focus on a lack of monetary income. This use of an income measure contrasts with living standards measures [Stephens et al, 2001, p. 80]. Indeed, there are significant mismatches in the groups that income and living standards measures identify as experiencing inadequate outcomes [Perry, 2002, p. 101].

A poverty threshold defines the level below which a monetary income is deemed inadequate. Different levels of inadequacy are reflected in different income thresholds. The income threshold chosen can make a significant difference to measured poverty [Perry, 2004, p. 26]. Two income levels widely used in New Zealand and overseas are the relative measures of $50 \%$ and $60 \%$ of equivalised median household annual income [Perry, 2004, p. 31].

A relative (distributional) poverty threshold terms people poor if their incomes are judged inadequate in relation to those of other people in the society in which they belong. Relative poverty thresholds indicate the extent that people "are, in effect, excluded from ordinary living patterns, customs and activities" [Hagenaars, in Stephens, 1989, p. 8]. An absolute (nominal) poverty threshold terms people poor if their incomes are below the level necessary to maintain a minimum standard of living that does not change over time [Stephens, 1989, p. 8]. ${ }^{2}$

People deemed poor on the basis of their individual incomes may reside in (and have access to the incomes of) non-poor households. Measured poverty thus reflects the income-sharing unit used in defining the poverty threshold (c.g., individuals, families, or households) [Perry, 2004, p. 24]. A household-based poverty threshold can account for the extent that people pool incomes and thus "function as an economic unit whose members have a common standard of living" [Jensen et al, 200I. p. 130]. ${ }^{3}$ Using a household-based threshold also, however, requires making assumptions regarding intra-houschold distributions of incomes [Apps et al, 1999, p. 393: O’Dea, 2000, p. 13].

As well as in their sharing of resources, households also differ in their relative income needs (their cost functions). Different levels of monetary incomes are required to provide the same outcomes for households in different circumstances. Variations in income needs can be accounted for by basing poverty thresholds on households hypothetical equivalised incomes (houscholds' actual incomes scaled to reflect their different cost functions). Equivalence scales effectively re-rank the income distribution [van de Ven et al, 2003, p. 2].

The simplest poverty measures are headcount measures, which state the number (or proportion) of households below the poverty threshold [Creedy, 1998, p. 82].
However, these measures ignore "the actual incomes of the poor, other than the fact that they fall below the poverty line. Two societies may have the same headcount poverty measure, but the total cost of bringing all the poor up to the line may be very different in each society" [Creedy, 1998, pp. 82-83].

A poverty measure reflecting the actual incomes of the poor is the poverty gap, which measures "the difference between income and the poverty line" [Creedy, 1998, p. 83]. The poverty gap may be adjusted for the extent that households fall below the poverty threshold (poverty depth) [Stephens et al, 2001, p. 83]. Two associated poverty measures are poverty reduction effectiveness (the ratio of benefits going to the pre-transfer poor to the total benefits needed by that group) and targeting efficiency (the extent that expenditure goes to the poor) [Stephens et al, 2001, p. 85]. These measures are discussed in greater detail below.

Previous behavioural responses (such as changes in hours of work and household structures) to government assistance will be reflected in poverty measures based on historical data. However, forecast poverty measures (based on estimated data) often do not consider future behavioural responses. Poverty measures also often do not consider the degree to which different people are in poverty at different times. A proportion of the poor may only be poor for a relatively short period due to income mobility in the population [O'Dea, 2000, p. 30]. Yet the possible erosion in the ability to earn over time and the need to replace consumer durables mean that those people in long-term poverty may have greater needs [Creedy, 1999, p. 411].

Perry [2004] estimated the reduction in headcount poverty rates from WFF with a non-behavioural microsimulation model (TaxMod-A). TaxMod-A calculates income tax liabilities and welfare entitlement based upon characteristics of the population and rules regarding eligibility and abatement of income tax and welfare programmes [Prebble et al (eds.), 1992, pp. 2944]. A population of families is derived from demographic, income, and expenditure data contained in the Household Economic Survey (HES) [Gordon, 1997]. Survey data can provide information on the large number of people who do not currently participate in various welfare programmes but who may nevertheless be affected by a policy change to programmes' parameters [Atkinson, 1989, p. 194]. Yet the sample of the population that this survey data is drawn from needs to be weighted up to estimate the entire New Zealand population. Thus in TaxMod-A each surveyed household is given a weighting representing the degree to which households of that type occur in the total population [Creedy et al, 2003, p. 3]. TaxMod-A also re-weights the HES sample to allow for changing rates of unemployment and adjusts income data for inflation (with separate inflators for wage, self-employed, and interest income). 
Working for Families and Headcount Poverty Rates

Table 1: Estimated impact of Working for Families on headcount poverty rates

\begin{tabular}{|c|c|c|c|c|}
\hline \multirow[b]{2}{*}{ Threshold (1998 Base) } & \multicolumn{2}{|l|}{ Children } & \multicolumn{2}{|l|}{ Whole Population } \\
\hline & $\begin{array}{l}50 \% \text { Household } \\
\text { Median }\end{array}$ & $\begin{array}{l}60 \% \text { Household } \\
\text { Median }\end{array}$ & $\begin{array}{l}50 \% \text { Household } \\
\text { Median }\end{array}$ & $\begin{array}{l}60 \% \text { Household } \\
\text { Median }\end{array}$ \\
\hline $\begin{array}{l}\text { Threshold in Equivalised Dollars } \\
\text { Per-Annum (June } 2005 \text { dollars) }\end{array}$ & $\$ 10,750$ & $\$ 12,900$ & $\$ 10,750$ & $\$ 12,900$ \\
\hline $\begin{array}{l}\text { Estimated Pre-Reform Rate for } 31 \\
\text { March } 2005\end{array}$ & $14.7 \%$ & $29.0 \%$ & $9.3 \%$ & $17.8 \%$ \\
\hline After Phase 1 & $9.3 \%$ & $24.2 \%$ & $7.3 \%$ & $15.8 \%$ \\
\hline After Full Implementation & $4.3 \%$ & $20.5 \%$ & $5.5 \%$ & $13.9 \%$ \\
\hline $\begin{array}{l}\text { Reduction in Measured Poverty } \\
\text { after Full Implementation } \\
\text { (Proportional Decrease) }\end{array}$ & $71.0 \%$ & $29.0 \%$ & $41.0 \%$ & $22.0 \%$ \\
\hline
\end{tabular}

Source: Perry, 2004, p. 35

Perry's [2004, p. 35] estimates of the impact of WFF on headcount rates of poverty are shown in table one. These rates are both for children and the population as a whole and use poverty thresholds of $50 \%$ and $60 \%$ of the equivalised median household annual income. These estimates are based on the Revised Jensen Scale, which converts actual household incomes into hypothetical equivalised incomes reflecting household size and the ages and numbers of children [Perry, 2004, p. 25]. These estimates assume no in changes labour market behaviour in response to WFF.

WFF was estimated to lower the child headcount poverty rate by around $70 \%$ using the $50 \%$ poverty threshold and by around $30 \%$ using the $60 \%$ poverty threshold. The reduction in total household headcount poverty was estimated as less than the reduction in child headcount poverty. WFF was estimated to lower the total household headcount poverty rate by around $40 \%$ using the $50 \%$ poverty threshold and by around $20 \%$ using the $60 \%$ poverty threshold [Perry, 2004, p. 35]. Perry [2004] argues the greater reduction in the child headcount poverty rate reflects the child-focus of WFF, as families without children (a large proportion of all households in poverty) do not receive increased assistance from the modelled changes. ${ }^{4}$

Although these estimates do not account for poverty depth (which would require attributing greater weight to reductions in poverty facing households further below the poverty threshold) the increased poverty reduction at the $50 \%$ threshold in comparison to the $60 \%$ threshold indicates that this reform package is targeted towards people further below the poverty threshold [Perry, 2004, p. 36]. This result also partly reflects the equivalence scale used to model these changes. The Revised Jensen
Scale increases the cost functions of families with multiple children (shifting them to lower levels in the

hypothetical equivalised income distribution). As the levels of assistance provided by WFF also increase as the numbers of children in the household increase then this targeting of assistance towards households further below the equivalised poverty threshold partly reflects this downwards re-ranking of families with multiple children.

\section{Estimating Financial Incentives to Work}

A second central objective of WFF is to improve incentives for work at low wages. To help evaluate the success of these reforms in achieving this objective this section of the paper canvasses some of the variety of ways of conceptualising and techniques for measuring financial incentives to work.

Welfare programmes may influence choices to supply labour on a number of margins. The extensive margin reflects decisions on whether to work at all. The intensive margin reflects decisions on how many hours (or weeks) to work [Stroombergen, 2003, p. 6]. The extensive margin reflects the change in the income available for consumption [Blundell, 1992, p. 20]. This change (the income effect) is reflected in the height of the budget constraint and can be illustrated with Average Tax Rates (ATRs). The intensive margin reflects the change in the financial return from an additional hour in work (the net wage). This change (the substitution effect) is reflected in the slope of the budget constraint and can be illustrated with Effective Marginal Tax Rates (EMTRs).

ATRs show the ratio of taxes paid (and benefits received) to income [Creedy, 1999, p. 411]. EMTRs show the proportion by which a dollar increase in gross 
income is reduced by income taxes and the abatement of welfare transfers. An EMTR is one minus the change in net income (after taxation and abatement of welfare transfers) resulting from earning an additional gross dollar [Nolan, 2003, p. 53; Prebble et al (eds.), 1992, pp. 7-13].

Whether changes to ATRs and EMTRs reinforce or offset each other depends on the case at hand and requires empirical analysis [Blundell, 1992, p. 16; Heady, 1993, p. 31]. For instance, removing abatement of the Family Assistance programmes from \$20,356 until \$27,500 (with no other policy changes) would:

- Not affect households with incomes below the change.

- Create an income effect (reduced ATRs) discouraging work and a substitution effect (reduced EMTRs) encouraging work for households with incomes between $\$ 20,356$ and $\$ 27,500$.

- Create an income effect (reduced ATRs) discouraging work for households with incomes above $\$ 20,356$.

The size of the responses of different groups depends on the compensated elasticity of labour supply and the numbers of people in the groups [Heady, 1993, p. 35]. However, households with the same gross wage may face different circumstances and have varying compensated elasticities of labour supply [Blundell, 1992, p. 24]. Indeed, New Zealand studies have shown that the labour supply of sole parents, part-time workers, secondaryincome earners, and teenage men tends to be more responsive to financial incentives than that of primary earners and prime aged males [Brosnan et al, 1989, p. 31; Maani, 1989: Maloney, 1997: Prebble et al (eds.), 1992].

Estimating ATRs and EMTRs pose a number of challenges. ATRs and EMTRs reflect the (often complex) interaction of income tax and welfare programmes. Different programmes use different entitlement and abatement schedules, eligibility criteria, definitions of what counts as income, income units (individual, family, and household), income periods (annual, fortnightly, or weekly), and implementation agencies (the Inland Revenue Department and the Ministry of Social Development). ATRs and EMTRs also differ among people with different characteristics, depending on factors such as hours of work, wage rates received, marital status, numbers and ages of children, availability of childcare, accommodation needs, and receipt of other assistance.

Estimating ATRs and EMTRs of people in partnered families pose particular difficulties. In partnered households the labour supply decisions are generally joint decisions. In these households when either the primary or secondary earner changes his or her supply of labour the total houschold income changes. As social welfare benefits and Family Assistance programmes abate against total household income the individual incentives facing primary and secondary earners are influenced by the earnings of their partners. However, due to the difficulty of modelling joint decisions, in this paper the changes in household income are modelled as individual decisions (where only one person makes a labour supply decision and the rest of the labour supply decisions in the household are held constant) [Prebble et al (eds.), 1992, pp. 37-38].

When people are faced with a decision on whether or not to make relatively small changes in income (e.g., from working a few extra hours) EMTRs are likely to illustrate the financial incentives applying to their decisions. Yet when people are considering relatively large changes in income (e.g., whether to work part-time or full-time) or when they are constrained in the degree to which they can change their hours of work (e.g., when they have employment contracts containing fixed hours) EMTRs are less likely to illustrate the financial incentives applying to their decisions. Also, the hourly wage rate that a person can earn influences the number of hours of work for which they face particular ATRs or EMTRs. If, for example, a person's hourly wage rate fell from $\$ 15$ to $\$ 10$ the numbers of hours of work over which they may face EMTRs created by the abatement of welfare programmes would increase.

However, although important, there are limits to the usefulness of ATRs and EMTRs. First, as well as these financial incentives people's labour supply reflect the uncertainty that they feel about the level of their likely work or social security income, non-financial considerations for entering or remaining in the work force (including self-esteem and fear of damage to future employment prospects), and social security programmes' administrative incentives (such as work tests) [Barr, 1999, p. 13; Wilson, 1996, pp 13-15]. Further, although people may appear to not face particular financial incentives (c.g., people located above or below the income levels at which incentives occur) they may still be affected by these incentives when making decisions (e.g., by being discouraged from locating at income levels associated with high disincentives to supply labour).

\section{Working for Families and EMTR Profiles}

The Treasury's estimates of the fiscal costs of WFF included estimates of the behavioural responses from the reforms. For the purposes of modelling fiscal costs conservative estimates of behavioural responses were used [Cullen et al, 2004, p. 22]. These behavioural estimates were prepared using the Melbourne Institute Tax and Transfer Simulator (see Creedy et al [2002] for a description of this model). The estimated behavioural responses from WFF were $2 \%$ of sole parents moving off a benefit into work as a result of the reforms and no net change for couples.

The effects of WFF on financial incentives to supply labour are illustrated in figures one and two. Figure one is an EMTR profile of a sole parent earning $\$ 10$ gross per-hour and with two children under 13. Figure two is an EMTR profile of a secondary earner earning \$15 gross per-hour and with two children under 13 and a working spouse. In figure two it is assumed that the primary earner works a fixed 40 hours per-week at $\$ 15$ gross per- 
hour. These wage rates have been selected as they closely approximate the median wages for these household types for 2003-04. In 2003-04 workers in the category of partnered people with working spouses and multiple children had a median wage of \$18.18. In contrast, single workers with children had a median wage of $\$ 12.67$ [Nolan, 2004, p. 8].

Figures one and two compare the EMTRs profiles arising from the 2003-04 welfare system with those arising from the welfare system when WFF is fully implemented (excluding the Family Tax Credit). These profiles contain changes to the Accommodation Supplement, which would vary among households according to accommodation costs, areas of residency, and incomes. Thus it is assumed that the household has an unabated level of Accommodation Supplement of the maximum for pre-reform region two, which will become the postreform region three, of $\$ 100$ increasing to $\$ 120$. As well as the Family Tax Credit, the EMTR profiles do not include childcare assistance and indirect taxes.

Although these profiles only illustrate EMTRs the impact of WFF on broader financial incentives to supply labour (including ATRs) is discussed below.

Figure 1: Impact of Working for Families on the EMTR profile of a sole parent earning \$10 per- hour and with two children (under 13

Source: Author's estimates, based on the 2003-04 and proposed 2007-08 welfare systems (excluding the Family Tax Credit, childcare assistance, and indirect taxes)

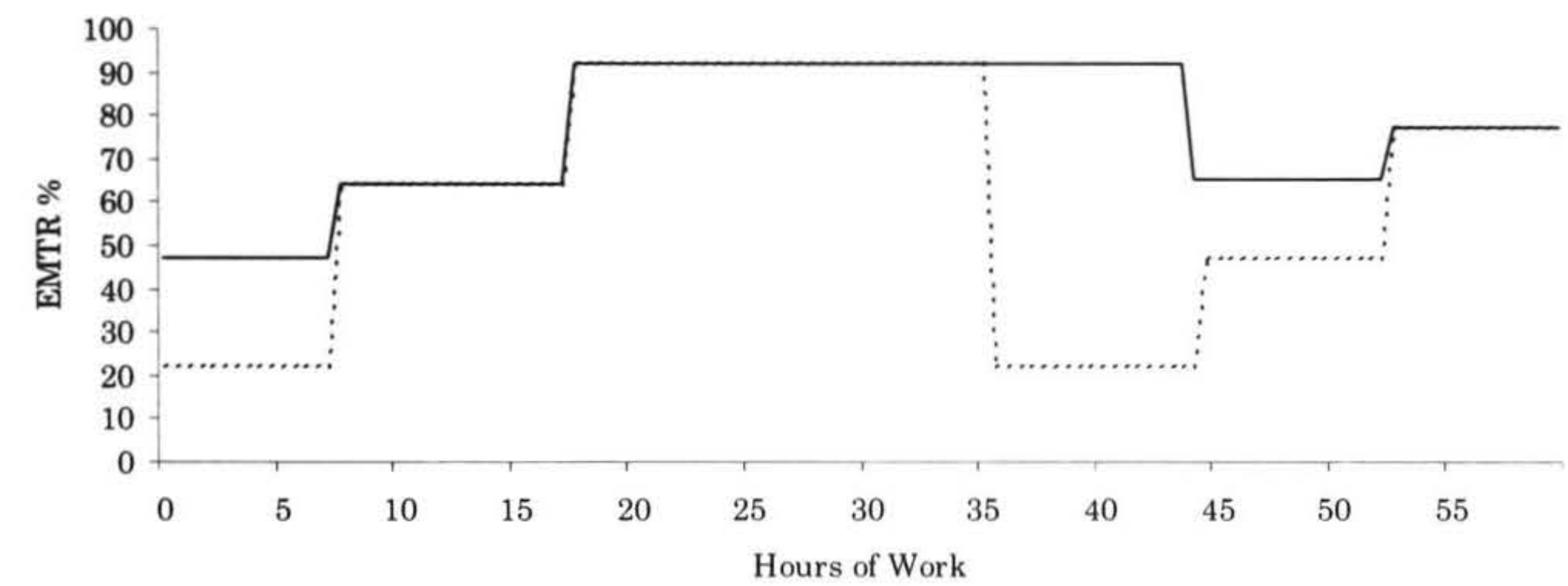

Before Working For Families (Excluding Childcare Changes) $\cdots \cdots$... When Fully Implemented

Figure 2: Impact of Working for Families on the EMTR profile of a secondary earner in a partnered household earning \$15 per-hour and with two children (under 13)

Source: Author's estimates, based on the 2003-04 and proposed 2007-08 welfare systems (excluding the Family Tax Credit, childcare assistance, and indirect taxes)

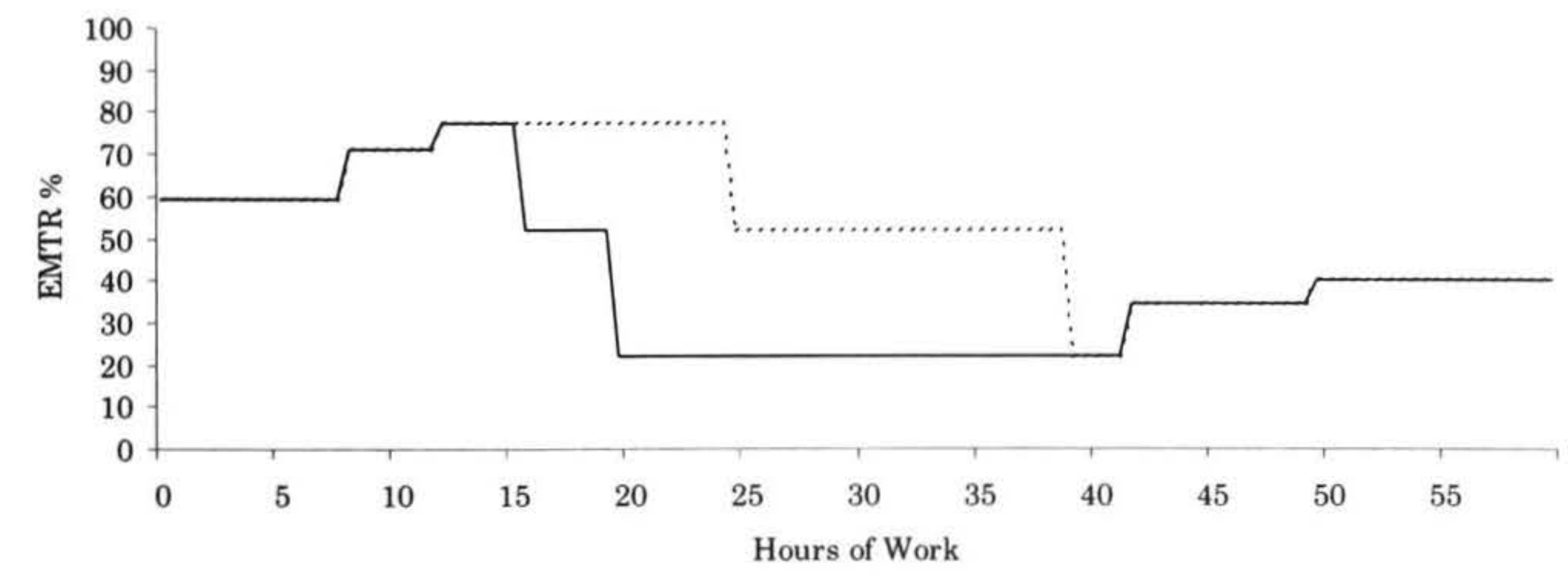

— Before Working For Families (Excluding Childcare Changes) $\cdots \cdots \cdots$ When Fully Implemented 
For sole parent households, on non-benefit income up to $\$ 80$ per-week the elimination of the abatement of the Accommodation Supplement while receiving a Domestic Purposes Benefit increases both the substitution effect encouraging work and the income effect discouraging work. If the substitution effect dominates the income effect then the overall result would be improved incentives for labour market participation of sole parent houscholds currently not participating in the labour market. At between $\$ 80$ and $\$ 360$ non-benefit income per-week WFF creates an income effect discouraging work effort. Depending on the strength of this income effect some sole parent households in this band could be encouraged to reduce their hours of work (particularly as there remains little incentive for increases in hours of work between $\$ 180$ and $\$ 360$ non-benefit income perweek). However, the delay in the abatement of Family Assistance and the increased incentives for some households to exit the main benefit early (due to the lower level of the base benefit and the increased value of the In-Work Payment) mean that at between $\$ 360$ and $\$ 530$ non-benefit income per-week WFF reduces EMTRs facing sole parents and consequently improves the substitution effect encouraging work at these incomes.

Overall WFF improves incentives for sole parent households to enter the labour market and to leap into work that pays between $\$ 360$ and $\$ 530$ per-week. Sole parent houscholds carning $\$ 180$ to $\$ 360$ non-benefit income per-week will continue to face high EMTRs (of $92.2 \%$ ) due to abatement of the Domestic Purposes Benefit. Further, sole parent households earning between $\$ 740$ and $\$ 1,200$ per-week (not shown in figure one) would face higher EMTRs and lower ATRs following WFF than before [Nolan, 2004, p. 17]. Lowering levels of abatement along with increasing levels of assistance at lower incomes come at this economic cost of shifting disincentives to supply labour further up the income distribution. However, given the relatively low median wage and relatively high proportion of part time work of sole parent households the dominant effect on sole parents is likely to be an improvement in their financial incentives to work.

For partnered households, if it is assumed that primary carners' incomes are a fixed $\$ 600$ per-week, when secondary income earners consider entering the labour market household incomes are already above the point at which the Unemployment Benefit is fully exhausted. Further, at this level when secondary income earners enter the labour market they immediately face abatement of Family Assistance and of the Accommodation Supplement as well as Personal Income Taxes and the ACC Earners' Levy. Consequently when secondary income earners consider earning up to $\$ 240$ per-week they face no improvement in their substitution effect and face an income effect discouraging work. Depending on the strength of this income effect some secondary earners in this band could be encouraged to reduce their hours of work or to no longer participate in the labour market.

Due to the increased levels of Family Assistance and the Accommodation Supplement and delays in the abatement of these programmes, the EMTRs resulting from abatement of these programmes have been shifted higher into the distribution of household incomes. Consequently at between $\$ 240$ and $\$ 600$ of earnings perweek secondary income earners face substitution and income effects discouraging increases in work.

Given the above assumptions regarding primary earners' incomes, overall WFF does not improve incentives for secondary income earners to enter the labour market and increases the disincentives they face when they increase their earnings to between $\$ 240$ and $\$ 600$ per-week. (Reducing the primary earner's fixed income or the secondary earner's wage rate would postpone but extend this increase in disincentives.) The impact of the reforms on secondary earners was a particular concern of the Department of Labour [Cullen et al, 2004, p. 24]. Based on experiences with work-based income tax assistance in overseas jurisdictions, such as the Earned Income Tax Credit in the United States, this increase in EMTRs will be likely to encourage secondary earners to drop out the labour market, rather than working or registering for unemployment assistance, and lead to some families in this income range choosing to reduce their market incomes [Eissa et al, 1999]. WFF effectively subsidises some secondary earners to stay at home.

\section{Behavioural Responses, Poverty Reduction Effectiveness, and Targeting Efficiency}

The section above concluded that the likely effect of WFF on financial incentives to work would be to encourage the labour supply of sole parents and discourage the labour supply of secondary earners in partnered households. These behavioural responses from WFF would in turn affect the reduction in poverty reduction effectiveness, reduction in headcount poverty rates, and targeting efficiency of the reforms.

The likely impact of the labour market behavioural responses from WFF on poverty reduction effectiveness, headcount poverty rates, and targeting efficiency are illustrated with hypothetical income distributions in figure three. The ordinate of the figure expresses equivalised household incomes and the abscissa expresses numbers of households. Illustrated in the figure are hypothetical post-transfer income distributions (both without (static) and with (behavioural) labour supply effects) and a pre-transfer income distribution. The comparisons between the pre-transfer and post-transfer distributions are for the same calendar year. $Y_{p}$ is the poverty threshold. $Y_{H}$ is a hypothetical point at which assistance from WFF is fully exhausted (creating a notch in the behavioural post-transfer line at this point. The lines remain apart due to the likely behavioural responses from other income tax and welfare programmes in operation).

Poverty reduction effectiveness is the ratio of benefits going to the pre-transfer poor to the total benefits needed by that group [Stephens et al, 2001, p. 85]. The total benefits needed by the poor are given by the area 
bounded by the poverty threshold, the pre-transfer income distribution, and the ordinate (the area $a b c$ in the figure). The benefits that go to the pre-transfer poor are given by the area bounded by the poverty threshold, the pretransfer income distribution, the ordinate, and the posttransfer income distribution (in the static case the area $e b c d$ ). Pre-transfer headcount poverty is given by the number of households at the point where the poverty threshold and the pre-transfer income distribution intersect $\left(N_{0}\right)$. Post-transfer headcount poverty is given by the number of households at the point where the poverty threshold and the post-transfer income distribution intersect (in the static case $N_{l}$ ). In order to simplify discussion this paper uses headcount poverty as a proxy for poverty reduction effectiveness. This assumption does not affect the conclusions of the paper.

Targeting efficiency indicates the extent that expenditure goes to the poor [Stephens et al, 2001, p. 85]. Targeting efficiency is reduced by spillover.

\section{Figure 3: Hypothetical Pre-Transfer and Post-Transfer Income Distributions for 2007}

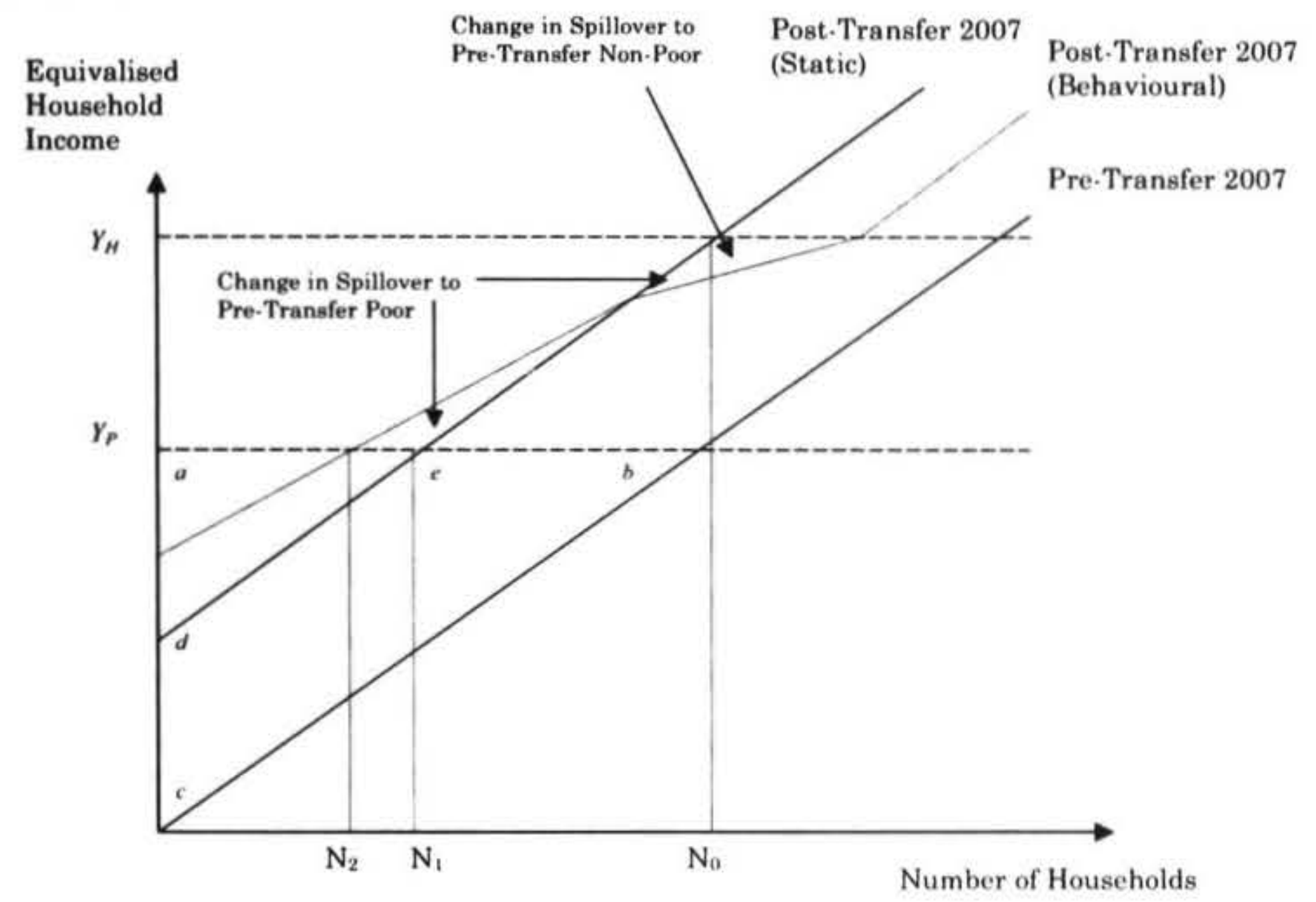

Source: Based on Creedy, 1996, p. 103

Spillover to the pre-transfer non-poor occurs when households with pre-transfer incomes above the poverty line receive some financial assistance. Spillover to the pre-transfer poor occurs when the transfers received by the pre-transfer poor are greater than those needed to lift their incomes to the poverty threshold [Creedy, 1996, pp. 102, 104; Stephens et al, 2001, p. 85].

The reduction in the headcount rate of poverty without taking behavioural responses into account is a movement from $N_{0}$ to $N_{l}$. WFF is likely to encourage sole parent households to enter the labour market and increase their hours of work. Further, if sole parents are concentrated at lower levels of household incomes (reflecting their relatively low median wages and hours of work), even after these household incomes are equivalised, WFF would reduce the numbers of households at low incomes. This behavioural response would mean that the reduction in the headcount rate of poverty from WFF would be the larger shift from $\mathrm{N}_{0}$ to $\mathrm{N}_{2}$. Thus, given these assumptions, Perry's [2004, p. 35] estimates for poverty reduction following WFF may be understated.

Targeting efficiency reflects the spillover of assistance to the poor and non-poor. WFF is likely to encourage secondary income earners to exit the labour market or reduce their hours of work. Further, if secondary income earners are concentrated in households at higher levels of household incomes, even after these household incomes are equivalised, WFF would reduce the numbers of households at higher incomes. Spillover to the pretransfer poor both increases and decreases. For those pretransfer poor households who increase their labour supply spillover increases if their post-transfer static incomes are above the poverty threshold or if behavioural changes lift them from below to above the poverty threshold. For those pre-transfer poor households whose labour supply decreases spillover decreases. The overall change in spillover to the pre-transfer poor would thus depend on the size and responsiveness of labour supply of the different groups. Spillover to the pre-transfer non-poor unambiguously decreases when behavioural considerations are taken into account.

The decrease in spillover to households who reduce their labour supply would come at an economic cost of increasing the excess burden associated with the welfare system. For instance, by "choosing to work less on average, workers will have lower incomes and thus will pay less taxes. Thus a change that would have been revenue-neutral for a fixed level of labour supply will, as a result of the reduction in work, produce a revenue loss. It is this revenue loss that represents the 'excess burden' of taxation" [Heady, 1993, p. 32]. The excess burden results from the higher taxes required to offset the reduced tax revenue from reductions in labour supply 
[Creedy, 2003, p. 3; Heady, 1993, p. 32; Slemrod, 1993, p. 362]. In evaluating WFF it is necessary to trade-off this increase in excess burden against the gains to society from the reduction in poverty from these reforms. Evaluating this trade-off requires value judgements to be made; the most notable of which is the evaluator's degree of aversion to poverty.

\section{Conclusions and Areas for Further Research}

This paper evaluated the effectiveness of WFF in reducing child poverty and improving the financial incentives for work at low wages. This paper identified that WFF will be likely to reduce child poverty, encourage the labour supply of sole parents, and reduce the supply of secondary income earners. These labour supply behavioural responses will increase the poverty reduction effectiveness and targeting efficiency of the reforms but at a cost of increasing the excess burden of the welfare system.

The findings of this paper could usefully be tested against more formal microsimulation modelling of the labour supply effects, poverty reduction effectiveness, and targeting efficiency of WFF. Modelling such as this could soon be undertaken in New Zealand when the Treasury complete development of a behavioural component (TaxMod-B) to their existing microsimulation model. The findings of this paper also highlight the importance of further research on changing labour market participation, hours of work, and work and family-life balance [Bryant et al, 2004; Singley et al, 2004; Varuhas et al, 2003]. The labour supply effects of WFF are most likely to be felt on the margin of participation in work and will consequently influence people's choices between being breadwinners or caregivers.

\section{Notes}

1. Helpful advice and comments on this paper were received from Associate Professor Bob Stephens and Dr. Paul Callister of the VUW School of Government. I am grateful for financial support for my research from the Ryoichi Sasakawa Young Leaders' Scholarship Committee and SPEaR Secretariat. All errors and omissions remain the responsibility of the author.

2. Economic growth will not lead to an increased measured incidence of poverty with a relative poverty threshold. Unless an absolute poverty threshold is adjusted for economic growth then over time an increasing proportion of the population will fall below this threshold [Jensen et al, 2001, p. 133].

3. An individual-based poverty measure can illustrate changes to the distribution of individual market earnings (an important component of household incomes).

4. Given limitations of TaxMod-A and the HES data Perry [2004] does not model the Accommodation Supplement and childcare changes. See Nolan [2003, pp. 35-37] for a discussion of the difficulties associated with modelling these forms of assistance. It is unclear if excluding this assistance would change the balance between the reduction in child and household headcount poverty, as while some of the increases in the Accommodation Supplement would go to families without children the reduction in child headcount poverty may also increase due to the increase in childcare assistance.

\section{References}

Apps, P. and R. Rees (1999). 'Individual versus Joint Taxation in Models with Household Production', Journal of Political Economy, vol. 107, no. 2, pp. 393-403

Atkinson, A. (1989). Poverty and Social Security, Harvester Wheatsheaf, New York

Barr, N. (1999). 'Fundamentals of Social Security Analysis', Australian Social Policy, issue 1, pp. 729

Blundell, R. (1992). 'Labour Supply and Taxation: A Survey', Fiscal Studies, vol. 13, no. 3, pp 15-40

Brosnan, P., M. Wilson, and D. Wong (1989). 'Welfare Benefits and Labour Supply: A Review of the Empirical Evidence', New Zealand Journal of Industrial Relations, 14, pp. 17-35

Bryant, J., V. Jacobsen, M. Bell, and D. Garrett (2004). 'Labour Force Participation and GDP in New Zealand', New Zealand Treasury Working Paper, no. 04/07, New Zealand Treasury, Wellington

Creedy, J. (1996). Fiscal Policy and Social Welfare: An Analysis of Alternative Tax and Transfer Systems, Edward Elgar, Cheltenham, United Kingdom

(1998). 'Measuring Poverty: An Introduction', The Australian Economic Review, vol. 31, no. 1, pp. $82-89$

(1999). 'Taxation, Redistribution and Progressivity: An Introduction', The Australian Economic Review, vol. 32 , no. 4, pp. 410-422

(2003). 'The Excess Burden of Taxation and Why it (Approximately) Quadruples When the Tax Rate Doubles', New Zealand Treasury Working Paper, no. 03/29, New Zealand Treasury, Wellington

Creedy, J., A. Duncan, M. Harris, and R. Scutella (2002). Microsimulation Modelling of Taxation and the Labour Market: The Melbourne Institute Tax and Transfer Simulator, Edward Elgar, Cheltenham

Creedy, J. and I. Tuckwell (2003). 'Reweighting the New Zealand Household Economic Survey for Tax Microsimulation Modelling', New Zealand Treasury Working Paper, no. 03/33New Zealand Treasury, Wellington 
Cullen, M. and S. Maharey (2004). 'Reform of Social Assistance: Working for Families Package', Cabinet Policy Committee

Eissa, N. and H. Hoynes (1999). 'The Earned Income Tax Credit and the Labour Supply of Married Couples', NBER Working Paper, w6856, National Bureau of Economic Research, Massachusetts

Gordon, R. (1997). 'Background to the Household Economic Survey', Consumers Price Index Revision Advisory Committee, Statistics New Zealand, Wellington

Heady, C. (1993). 'Optimal Taxation as a Guide to Tax Policy’, Fiscal Studies, vol. 14, no. 1, pp. 15-41

Jensen, J. and V., Krishnan (2001). 'Tracking Living Standards: Is It Done Better by EDY or HEDY?' Social Policy Journal of New Zealand, issue 16, pp. 127-154

Maani, S. (1989). 'The Unemployment Benefit, Unemployment Duration and Wage Requirements of Job Seekers in New Zealand', New Zealand Economic Papers, 21, pp. 41-55

Maloney, T. (1997). Benefit Reform and Labour Market Behaviour in New Zealand, Institute of Policy Studies, Wellington

Nolan, P. (2003). 'New Zealand's Social Assistance System: Financial Incentives to Work', New Zealand Treasury Working Paper, no. 03/18, New Zealand Treasury, Wellington

(2004). 'When Work Does Not Pay: Family Structures and Poverty Traps in New Zealand's Social Security System', paper presented at the Forty Fifth Annual Conference of the New Zealand Association of Economists, Wellington

O'Dea, D. (2000). 'The Changes in New Zealand's Income Distribution', New Zealand Treasury Working Paper, no. 00/13, New Zealand Treasury, Wellington

Perry, B. (2002). 'The Mismatch Between Income Measures and Direct Outcome Measures of Poverty', Social Policy Journal of New Zealand, issue 19, pp. 101-127
(2004). 'Working For Families: The Impact on Child Poverty', Social Policy Journal of New Zealand, issue 22, pp. 19-54

Prebble, M. and P. Rebstock eds. (1992). Incentives and Labour Supply: Modelling Taxes and Benefits, Institute of Policy Studies, Wellington

Singley, S. and P. Callister (2004). 'Polarisation of Employment, 1986-2002: New Zealand in the International Context', Centre for Social Research and Evaluation Working Paper 06/04, Ministry of Social Development, Wellington

Slemrod, J. (1993). 'Do We Know How Progressive the Income Tax System Should Be?', National Tax Journal, vol. 36 , no. 3 , pp. 361-370

Stephens, R. (1988). 'Issues in the Measurement of Poverty and Standards of Living', Department of Economics Discussion Paper, no. 48, Victoria University of Wellington

Stephens, R. and C. Waldegrave (2001). 'The Effectiveness of the Transfer and Tax System in Reducing Poverty in 1998', Social Policy Journal of New Zealand, issue 16, pp. 77-107

Stroombergen A. and T. O'Brien (2003). 'Labour Supply in New Zealand: A Preliminary Analysis Using Unit Record Data from the Household Labour Force Survey', Labour Market Policy Group, Department of Labour, Wellington

van de Ven J. and J. Creedy (2003). 'Taxation, Reranking and Equivalence Scales', New Zealand Treasury Working Paper, no. 03/11, New Zealand Treasury, Wellington

Varuhas, J., L. Fursman, and V. Jacobsen (2003). 'Work and Family Balance: An Economic View', New Zealand Treasury Working Paper, no. 03/26, New Zealand Treasury, Wellington

Wilson, M. (1996). 'Institutional Labour Economics, Benefit Levels and Unemployment', Social Policy Journal of New Zealand, issue 6, pp. 2-22 